\title{
Er der kønsforskelle i hjernens bearbejdning af sprog?
}

\author{
MiKKEL WALLENTIN \\ Center for Semiotik, Århus Universitet, Danmark \\ Center for Funktionelt Integrativ Neurovidenskab, Århus Universitetshospital, \\ Danmark
}

\begin{abstract}
It is a common assumption, also in a Danish context, that sex-differences exist in the way language is processed by the brain. This paper reviews data investigating sex differences in language and language cortex using many different methods. Girls have an early advantage during language acquisition, but this seems to disappear around the age of six years. Differences in the neural underpinnings of language have been reported, e.g. as a greater lateralization of language in males compared to females. This difference is thought to be mediated by a larger corpus callosum in females (the fiber bundle connecting the two cerebral hemispheres). But a look at recent meta-analyses of the findings from this field shows that neither of these assumptions is supported by evidence. Further, larger studies of the regional gray matter distribution in the brain show no systematical language related differences between males and females. Apparent differences can be found in deficits such as stuttering, dyslexia, schizophrenia and autism that have a certain connection to language. Common to these deficits, however, is that language problems seem to be secondary traits. Language function, as measured by the WADA-test, as studied in patients with aphasia and in normal ageing also fails to exhibit sex differences. The overall conclusion therefore is that outspoken sex-differences in language processing is not supported by data.
\end{abstract}

\section{INTRODUKTION}

Køn og kønsforskelle er elementært spændende. John Grays bog Moend er fra Mars, Kvinder er fra Venus (Gray 1992), som argumenterer for store psykologiske forskelle mellem kønnene er således oversat til mere end 40 sprog og solgt i over

Christensen, Ken Ramshøj (ed.), Cognition/Kognition, Århus: Statsbiblioteket

Tidsskrift for Sprogforskning, årgang 7, 2009

Artikel nr. 3, Wallentin, Mikkel, 35 pp.

http://ojs.statsbiblioteket.dk/index.php/tfs/index 
30 millioner eksemplarer (http://www.marsvenus.com). Og nyhedsmedierne flokkes også om at fortælle historier om de mange forskelle, der er mellem mænd og kvinder. Når kognitionsforskere kontaktes af journalister, så er det ofte med spørgsmål, der omhandler kønsforskelle. Denne artikel, dens engelsksprogede søsterartikel (Wallentin 2009), og en tidligere kortere dansk version (Wallentin 2007) er således skrevet på foranledning af en avisartikel (Frank 2007), hvori der blandt andet stod:

\begin{abstract}
I det hele taget er det et gennemgående tema, at mænd viser lateralisering - altså fortrinsvis bruger områder i den ene hjernehalvdel til løsning af diverse opgaver, mens kvinder typisk trækker på områder spredt i begge hjernehalvdele. En observation, som passer godt med, at hjernebjælken - et bredt bånd af kommunikations-forbindelser mellem de to hjernehalvdele - er forholdsvist større hos kvinder.
\end{abstract}

Lateralisering er interessant i sprogforskningsøjemed, fordi det er i sproget, vi ser den største grad af lateralisering i hjernefunktion hos mennesker. Skader på sprogfunktionen er således næsten altid forbundet med skader på venstre halvdel af hjernen. Dette har været kendt i hvert fald siden Paul Brocas banebrydende studier fra 1860'erne (Broca 1861). Derfor er det vigtigt at vide, hvad der er op og ned i denne strøm af rapporter om kønsforskelle, og i hvor høj grad det er relevant for sprogforskningen at beskæftige sig med spørgsmålet.

I grundbøger i neuropsykologi og neurolingvistik finder man ofte opregning af kønsforskelle i sprogfunktion. Oftest fortælles det, at kvinder har en fordel i såkaldte verbal fluency-opgaver, hvor det gælder om at nævne så mange ord som muligt fra en specifik kategori eller med et specifikt begyndelsesbogstav (f.eks. Kolb/Whishaw 2001: 558, Mildner 2008: 41, Pinker 2007: 85-86). Desværre er det ofte vanskeligt at se, hvor disse resultater stammer fra. Dette er ikke bare tilfældet med grundbøger og mere populære publikationer, men også i egentlige videnskabelige artikler. I en rapport om en undersøgelse af verbale og nonverbale kønsforskelle (Weiss et al. 2003) kan man f.eks. finde følgende citat uden nogen som helst referencer til at understøtte udsagnet:

Kvinder har en tendens til at være bedre end mænd til at identificere matchende objekter, en evne kaldet perceptionshastighed. Kvinder udviser også bedre almindelige sprogevner, såsom verbal fluency, taleartikulation, grammatiske evner og brug af længere og mere komplekse sætninger. (min oversættelse) 
Lignende citater kan findes i alle de ovenstående referencer.

Adskillige andre påstande om kønsforskelle i hjernens struktur og funktion er blevet fremført (f.eks. Cahill 2006), ikke mindst omkring cortikale lateraliseringsforskelle i sprogfunktionen (f.eks. Shaywitz et al. 1995). Artiklen af Shaywitz og kollegaer, publiceret i det anerkendte tidsskrift Nature, fremfører argumenter for forskelle i sprog-lateralisering, og den er blevet citeret mere end 500 gange af andre videnskabelige publikationer, hvilket viser noget om den interesse, der er for denne type undersøgelser, både i den videnskabelige verden og i den bredere offentlighed.

Denne artikel præsenterer en detaljeret gennemgang af de forskellige eksperimentelle tilgange, der er til spørgsmålet om kønsforskelle i måden, vi bearbejder sprogindtryk på. Artiklens fokus er altså sprogprocesser, og de hjernestrukturer, der kunne tænkes at ligge til grund for forskelle mellem mænd og kvinder. Der henvises primært til større studier med mange forsøgspersoner, da disse giver de mest troværdige resultater.

\subsection{Mulig evolutionær oprindelse}

Men før vi kigger på de faktiske undersøgelser, er et indblik i baggrunden for overhovedet at overveje muligheden af kønsforskelle i sproget på sin plads.

\subsubsection{Joeger-samler-hypotesen}

Kvinder er født med langt flere hjernetråde over til den venstre hjernehalvdel, der eksempelvis styrer evnen til at lytte og tale. Det gør det muligt for kvinder at tale i mobil og lave mad med højre hjernehalvdel samtidig. Mændene derimod er ikke udstyret med bredbånd mellem hjernehalvdelene og skal aktivt kalde venstre hjernehalvdel op, hver gang de skal formulere sig og lytte. [...] Stenaldermændene behøvede kun at bruge den rummelige højre hjernehalvdel til at lokalisere byttet, tage chancer og finde vej tilbage til bopladsen. Kvinderne skulle derimod kunne få hele bopladsen til at fungere, hvor der konstant er gang i mange ting, der også kræver venstre hjernehalvdel (forfatter Ann-Elisabeth Knudsen, Nyhedsavisen, 28. juni 2008)

Joeger-samler-hypotesen (se f.eks. Kolb/Whishaw 2001, Mildner 2008) antager at kønsforskelle opstod som en konsekvens af den arbejdsdeling, som fandtes mellem kønnene i forhistorisk tid. Mændene var primært jægere, mens 
kvinderne var samlere, siges det. Ifølge denne teori har mænd derfor udforsket store områder under jagten, hvilket medførte, at de blev udstyret med bedre stedsans, mens kvinderne holdt sig på et mindre område i større grupper og derfor havde fordel af at udvikle bedre redskaber for social adfærd, heriblandt sproglige evner. Joeger-samler-teorien antager derfor, at kvinder generelt er bedre til sprog end mænd.

\subsubsection{Seksuel udvælgelse}

En anden mulig evolutionær oprindelse til sprogforskelle mellem kønnene er blevet bragt frem af Geoffrey Miller (Miller 2000) og senere på dansk af Tor Nørretranders (Nørretranders 2003). Ifølge Miller er sprog i det mindste delvist udviklet som et fitness-display i parringsspillet. At være veltalende kan altså i den forstand ses som et tegn på, at man generelt er et sundt individ, hvis gener er værd at give videre. Sproget svarer i denne form for tankegang til påfuglens prangende fjer. Stærkt synlige fjer bidrager ikke til bedre overlevelses-chancer, sådan som f.eks. vinger, øjne eller camouflage gør. Der er derfor ingen primær overlevelsesmæssig grund til at udvikle farverige fjer, tværtimod. Men hvis det af en eller anden grund bliver anset som "smukt" inden for en given art, så kan disse egenskaber alligevel udvikles, fordi "smukke" eksemplarer af arten har en tendens til i højere grad at få mulighed for at videregive gener til næste generation. Men dynamikken inden for den seksuelle udvælgelse medfører, at det i højere grad er hannerne, der udviser de prangende træk, mens hunnerne har magten til at vælge hvilken han, der er den "smukkeste". Hunnerne har derfor brug for at være gode til at skelne "smukke" fra "grimme" fitnessindikatorer. En sådan teori overført på sprog forudsiger altså store forskelle mellem mandlige og kvindelige sprogevner. Kun sunde mænd vil have evner og tid til at udvikle og frembringe inciterende tale. Mænd bør altså ifølge denne tankegang være bedre talere, og deres geners videreførelse afhænger af, at de får vist deres evner frem, mens kvinder på den anden side, burde være bedre lyttere og bedre til at forstå tale, sådan at de kan adskille gode talere fra de mindre gode. Anekdotisk kan denne teori forsvares ud fra den observation, at anerkendte forfattere - i hvert fald indtil for få år siden - i højere grad var mænd end kvinder, mens kvinder køber og læser flere bøger end mænd (Halpern 2000, se også Nørmark/Andreassen 2007 for en dansk introduktion til emnet). ${ }^{1}$ 
Overført på sprog har begge disse teoretiske standpunkter imidlertid vigtige svagheder. For det første er de gensidigt modstridende, og den ene må derfor nødvendigvis være forkert, men hvordan afgør man hvilken? Da sproget er en unik menneskelig egenskab, er det stort set umuligt at foretage sammenligninger på tværs af arter. Dette er afgørende for studiet af evolutionære processer. Dermed får både joeger-samler-teorien og teorien om seksuel udvælgelse som motor i sprogudviklingen samme problem: De bliver meget vanskelige at falsificere endsige overhovedet undersøge videnskabeligt (Gannon 2002). Alligevel er de værd at nævne, da de tjener som baggrund for en stor del af den forskning, der gøres i sproglige kønsforskelle.

\section{ADFARDSFORSKELLE I DEN NORMALE BEFOLKNING}

\subsection{Verbal Fluency}

Den sproglige opgave der oftest rapporteres at have givet en kønsforskel, er den såkaldte verbal fluency-opgave (f.eks. Kolb/Whishaw 2001, Mildner 2008, Pinker 2007, Sommer et al. 2004, Weiss et al. 2003). Verbal fluency-opgaven går i al sin enkelhed ud på at forsøgspersonen nævner så mange ord som muligt i løbet af et minut. Sædvanligvis er testen opdelt i en "leksikon"-del og en "kategori"-del. I leksikon-delen er opgaven at sige så mange ord som muligt med et specifikt begyndelsesbogstav, oftest bruges $\mathrm{F}, \mathrm{A}$ og $\mathrm{S}$. I kategori-delen bedes forsøgspersonen nævne så mange medlemmer af en overordnet kategori som muligt. Som regel bruges "dyr" som overordnet kategori.

Som eksempel kan nævnes Weis et al. (Weiss et al. 2003), der undersøgte 97 college-studerende (51 kvinder, 46 mænd) og fandt at kvinder havde en signifikant fordel i leksikon-opgaven $(\mathrm{p}<0.02)$, men at der ingen signifikant forskel var i kategori-opgaven. $(\mathrm{p}<0.08)$. Uheldigvis var disse grupper ikke matchede i forhold til en anden demografisk variabel, nemlig alder ( $<<0.002)$, og mændene blev $\mathrm{i}$ en anden test målt til at have en signifikant højere verbal IQ $(\mathrm{p}<0.004)$. Dermed viser resultaterne af verbal fluency-opgaven sig ikke bare at være svage (med p-værdier tæt ved signifikans-grænsen på 0.05), men fortolkningen af resultaterne er vanskelig grundet de forskellige andre variable, som ikke kan skilles fra resultaterne. Hvis man for eksempel bliver bedre eller dårligere til verbal fluency-opgaven efterhånden som man bliver ældre, er det så en effekt af alder eller en effekt af køn, som testen har vist? Trods disse 
indbyggede problemer opsummeres resultaterne på følgende måde i sammenfatningen af artiklen:

Overordnet set har kvinder en tendens til at være bedre end mænd på de fleste sproglige tests. (Weiss et al. 2003, min oversættelse)

Eksemplet viser, hvordan man skal være varsom i sine fortolkninger af kønseffekter. Der er næsten altid en eller anden variabel, som man har glemt at matche, og den eneste måde at overkomme det problem på er ved at bruge meget store grupper af forsøgspersoner.

Tombaugh og samarbejdspartnere satte sig for at gøre netop dette og målte verbal fluency hos 1.300 personer (Tombaugh et al. 1999). De satte boder op i indkøbscentre ved sociale arrangementer og i rekreative områder. I denne meget store gruppe fandtes absolut ingen forskel mellem mænd og kvinder. I leksikonopgaven kunne mænd i gennemsnit nævne 37 ord på et minut, mens kvinder nævnte 37,8 ord. I kategori-opgaven lykkedes det mænd at nævne 17,4 dyr, mens kvinder nåede 16,5 dyr. Ingen af disse forskelle var signifikante. Derimod observeredes der en klar effekt af både alder og uddannelsesniveau. Præcis de variable, der ikke var matchede i Weiss et al.-artiklen.

På den baggrund kan køn ikke siges at være signifikant forbundet med evner i verbal fluency-opgaven, når der tages højde for effekten af alder og uddannelsesniveau. ${ }^{2}$

\subsection{Sprogevner generelt}

Hyde/Linn (1988) foretog en meta-analyse af 165 amerikanske publikationer med både børn og voksne som forsøgspersoner. De tests der anvendtes inkluderede både test af ordforråd, forståelse af analogier og anagrammer, læseforståelse, tale og anden verbal kommunikation, skriveøvelser, den amerikanske Scholastic Aptitude Test (SAT), som bruges ved adgang til videregående uddannelser, og andre generelle sproglige kompetencetests. 44 (27\%) af artiklerne rapporterede, at kvinder var signifikant bedre end mænd, 109 studier (66\%) fandt ingen signifikant forskel, og 12 artikler (7\%) rapporterede at mænd var bedre end kvinder. Sammenlagt viste dette en svag, men signifikant effekt til fordel for kvinderne, men når effektstørrelsen af de forskellige forsøg 
blev vægtet med antallet af testede forsøgspersoner, så vendte billedet til en svag effekt til fordel for mændene, først og fremmest fordi det største studie (med mere end 900.000 medvirkende) fandt en svag maskulin fordel. På baggrund af dette konkluderer forfatterne, at

Vores meta-analyse giver stærke beviser for, at størrelsen af kønsforskelle i sprogevner på nuværende tidspunkt er så små, at den reelt set kan siges at være nul. (Hyde/Linn 1988: 64, min oversættelse).

Som en interessant pointe kan det påpeges, at Hyde og Linn observerede en statistisk signifikant effekt af kønnet på forfatteren til artiklen på tværs af de 165 rapporter. Artikler med en kvindelig hovedforfatter var mere tilbøjelige til at tilskrive kvinder en sprogfordel end artikler hvor den første forfatter var en mand.

\subsection{Sprogtilegnelse}

Den mest anvendte test til måling af tidlig sprogtilegnelse er den såkaldte MacArthur-Bates Communicative Development Inventories (Fenson et al. 1994) også kendt som CDI. Fenson og samarbejdspartnere (1994) undersøgte 1.803 og Feldman et al. (2000) undersøgte 2.156 sociodemografisk spredte et- og to-årige amerikanske børn. Børnene blev vurderet af deres mødre $i$ en spørgeskemaundersøgelse, der spurgte om børnenes kendskab til de mest almindelige ord. En signifikant effekt af køn blev fundet hos både de et- og toårige, både når det kom til størrelsen af ordforråd på forståelsessiden og på udtrykssiden. Piger havde signifikant større ordforråd end drenge, selvom forskellen var meget lille og kun redegjorde for $1-2 \%$ af variansen i data. Fundene synes imidlertid at være robuste og er blevet gentaget i forsøg med store grupper børn både på svensk (Berglund et al. 2005) og dansk (Bleses et al. 2008). Den svage effekt gør imidlertid fortolkningen ret vanskelig. Signifikante tidlige sprogforskelle mellem drenge og piger er også fundet med andre, mere eksperimentator-kontrollerede metoder (f.eks. Bornstein et al. 2004). Men her er det værd at nævne, at i Bornstein og samarbejdspartneres forsøg med 329 1-6 årige børn syntes kønsforskellen at forsvinde omkring det sjette leveår. Dette kan evt. bringe overensstemmelse mellem de tidlige fund af kønsforskelle og manglen på effekt hos de voksne. 
Dermed passer disse fund ind i en forklaringsramme, hvor tidlige sprogforskelle er del af en større mere generel udviklingsmæssig forskel mellem kønnene, som også kan findes i nonverbale domæner (Galsworthy et al. 2000). Den højere andel af autister blandt drenge kan evt. også forklare noget af den målte forskel (se afsnit om udviklingsmæssige sprogforstyrrelser nedenfor). I det første leveår vil der blandt de normalt-udviklende børn gemme sig autister, der endnu ikke har fået en diagnose. Men efterhånden som børnene bliver ældre vil disse børn blive diagnosticerede og dermed blive fjernet fra gruppen af normaltudviklende og ikke længere bidrage til den observerede kønsforskel. I hvilken grad dette kan forklare kønsforskellen i tidlig sproglig kompetence vides ikke. Dette kræver et stort longitudinalt studie at afgøre, som endnu ikke er gennemført.

Der er altså en lille, men robust forskel mellem drenge og piger i den tidlige sproglige udvikling. Men den fordel, som pigerne har til at begynde med, er ikke sprogspecifik og synes at forsvinde omkring det sjette leveår.

\subsection{Verbal hukommelse}

Kramer et al. (Kramer et al. 1988) testede 68 mænd og 68 kvinder, på samme alder og uddannelsesniveau, på den såkaldte California Verbal Learning Test (CVLT), hvor forsøgspersoner genkalder sig lister af ord over forskellige perioder. Kvinder klarede sig signifikant bedre end mænd i dette forsøg. Men forskelle observeredes også i måden mænd og kvinder gik til forsøget på. Kvinder organiserede i højere grad deres indre lister efter semantiske principper, mens mændene i højere grad forsøgte at huske listerne, altså at genkalde ordene i samme rækkefølge, som de var blevet præsenteret. Dette fund kunne tyde på, at kvinder i denne type test bruger en mere aktiv og effektiv måde at organisere ordlisten på.

I en senere undersøgelse testede Kramer og samarbejdspartnerere børn (5-16 år) med den samme test (Kramer et al. 1997). 401 drenge og 410 piger deltog i en børnevenlig version af CVLT. Igen blev kønsforskelle observeret på alle alderstrin og igen var piger bedre end drenge. Der var ingen interaktion med alder, hvilket indikerer, at effekten er stabil på tværs af alderstrin. Forfatterne peger på, at drengene faktisk scorede bedre på en test af størrelsen af ordforråd. Så forskellen her skyldes ikke en forskel i primære sproglige kompetencer, men igen at piger 
tilsyneladende benytter sig af en anden mnemoteknik end drengene, der i dette tilfælde er mere effektiv.

Piger synes altså at være bedre til at huske ordlister, men igen synes effekten ikke primært at skyldes et overordnet bedre sprog, men i stedet, at pigerne er tilbøjelige til at gruppere ordene efter deres betydning, mens drenge forsøger at huske listen, som den blev præsenteret, hvilket i denne sammenhæng er mindre effektivt. Hvorvidt denne effekt vedbliver at eksistere på tværs af andre typer opgaver vides ikke.

\subsection{Lateraliseret adfærd}

Lateralisering hidrører sig til det faktum, at vores krop ved første øjekast er spejlet omkring det plan, der går gennem næsen ud af baghovedet, sådan forstået at vi på hver side af dette skel har det samme, f.eks. har vi to arme, to ben, to øjne og to hjernehalvdele. Ved nærmere eftersyn er vi dog ikke helt så symmetriske. De fleste af os er således mere tilbøjelige til at bruge højre hånd end venstre, og hos de fleste mennesker sidder de primære sprogområder i venstre side af hjernen. Dette kan undersøges med teknikker, der forsøger at levere forskellige stimuli til de to hjernehalvdele.

Når det er interessant i denne sammenhæng, så skyldes det en vidt udbredt antagelse om, at kvinder er mindre lateraliserede i sprogbearbejdningen end mænd. Denne antagelse kan spores i hvert fald tilbage til Harris (1978) og McGlone (1980), og som det indledende aviscitat (Frank 2007) understreger, så er det en antagelse, som ofte tages mere eller mindre for givet.

Som undersøgelse af denne påstand udførte Boles (Boles 2005) et stort studie med opgaver, der konsekvent viser en stor lateraliserings-effekt. Blandt disse var to sprogopgaver: I den ene opgave ( $\mathrm{n}=446,123$ kvinder, 323 mænd) skulle forsøgspersonerne genkalde enstavelsesord, som de var blevet præsenteret for i et såkaldt dikotisk lytte-forsøg, hvor forsøgspersonen hører to ord ad gangen, et præsenteret til hvert øre i hovedtelefoner. Begge køn huskede langt flere ord der var præsenteret til højre øre. Input til højre øre sendes primært, men ikke udelukkende til venstre del af hjernen. Ingen signifikant effekt af køn kunne måles. I en anden opgave så forsøgspersonen ( $\mathrm{n}=536,149$ kvinder 387 mænd) forskellige ord på hver sin side af synsfeltet. En pil udpegede hvilket ord, der 
skulle gentages, og forskelle i responstid blev målt. Igen viste forsøgspersoner sig generelt at være hurtigere, når ordet blev vist i den højre del af synsfeltet, men ingen signifikant effekt af køn kunne måles (P>0.05).

\subsection{Lateraliseret hjernefunktion: Fund fra skanningsstudier}

Et antal skanningsstudier har undersøgt kønsforskelle i hjernens sprogprocesser og fundet mere bilaterale aktiveringsmønstre hos kvinder end hos mænd (f.eks. Kansaku et al. 2000, Phillips et al. 2001, Shaywitz et al. 1995). Men da Sommer et al. $(2008,2004)$ foretog en meta-analyse af først 14 siden 26 undersøgelser af sproglateralisering (med i alt mere end 2.000 forsøgspersoner) fandt de kun en ikke-signifikant effekt af køn. Og de fandt ingen forskel mellem ordproduktionsforsøg (f.eks. verbal fluency-opgaver og verbums-generering) og sprogforståelsesforsøg (semantisk stillingtagen). Et mindre lateraliseringsforsøg hos børn ( $\mathrm{n}=48)$ fandt heller ingen kønsforskelle (Wood et al. 2004).

\section{KøNSBETINGEDE FORSKELLE I HJERNESTRUKTURER}

\subsection{Resulter for hele hjernen}

Selv om det ikke er relateret til sprog og effekten er ukendt, er det værd at notere sig, at der findes anseelige kønsforskelle i mænds og kvinders hjerner. Mænd har gennemsnitligt større hjerner end kvinder. Mænds hjerner er cirka otte procent (svarende til 100 ml.) større end kvinders. Og denne forskel er robust på tværs af studier. (f.eks. Chen et al. 2007, Good et al. 2001, Kruggel 2006). Mænd har også overordnet set mere grå substans end kvinder (Chen et al. 2007, Good et al. 2001, Kruggel 2006, Lemaitre et al. 2005).

I en post-mortem undersøgelse af 62 mandlige og 32 kvindelige hjerner estimerede Pakkenberg og og Gundersen (1997) antallet af nerveceller i neocortex til 19 milliarder i den kvindelige hjerne og 23 milliarder i den mandlige hjerne, altså en forskel på 16 procent. De undersøgte hjerner dækkede et aldersspektrum fra 20-90 år. Undersøgelsen viste, at i løbet af denne tid mistes cirka 10 procent af alle neocortikale neuroner hos begge køn. Køn og alder var derfor de vigtigste determinanter for antallet af neuroner i neocortex. Kønsforskelle i neural densitet, altså i antallet af hjerneceller pr. volumenenhed blev ikke fundet i dette forsøg, og overraskende nok spillede kropsvægt ikke nogen signifikant rolle. Forsøget estimerede forskellen i antallet af hjerneceller 
mellem de to hjernehalvdele til 186 millioner (flest celler i venstre hjernehalvdel). Der var ingen kønsforskelle på dette estimat.

\subsection{Regionale forskelle i størrelsen af grå substans}

Større morfologiske forskelle kendes fra post-mortem-studier af menneskehjerner i et område af hypothalamus, som menes at være knyttet til seksuel adfærd og reproduktion. Nucleus intermedius hypothalami, en cellekerne i det præoptiske område af hypothalamus kaldes ligefrem den seksuelt dimorfe kerne (The Sexually Dimorphic Nucleus). Dette område er 2-2,5 gange større og indeholder 2,2 gange flere neuroner hos mænd end hos kvinder (Hofman/Swaab 1989, Swaab/Fliers 1985). Disse forskelle findes også hos en mængde andre pattedyr, f.eks. rotter, mus, hamstere, marsvin, ildere og aber og de regnes for i samvirken med kønshormoner at styre seksuelt differentieret adfærd (Hofman/Swaab 1989). Det er derfor usandsynligt, at de er direkte involverede i nogen former for sprogfunktion.

Der findes efterhånden et antal større studier af kønsforskelle i hjernestrukturer hos voksne. De fleste bruger en teknik kaldet voxel-baseret morfometri eller VBM. Metoden går ud på at lave strukturelle skanninger af forsøgspersonerne og derefter anvende non-lineære algoritmer til at tilpasse form og størrelse mellem forsøgspersonernes hjerner på det overordnede plan. Herefter kan man så statistisk sammenligne grupper af hjerner og lede efter forskelle i mindre områder (Ashburner/Friston 2000). To store VBM-undersøgelser har kigget på kønsforskelle i hjernestrukturer (Chen et al. 2007, Good et al. 2001). Good og samarbejspartnere (2001) undersøgte 465 raske voksne forsøgspersoner med VBM (200 kvinder, 265 mænd, i alderen 17-79 år) og Chen og samarbejdspartnere (2007) skannede 411 personer (227 kvinder og 184 mænd i alderen 44-48 år) fra en randomiseret gruppe. Begge forsøg fandt en mængde forskelle mellem mænds og kvinders hjerner, men overraskende nok var det eneste overlap i resultaterne, at kvinder synes at have mere grå substans i den forreste del af den struktur, som hedder gyrus cingularis. Denne forskel er også blevet observeret $\mathrm{i}$ et tidligere studie (Paus et al. 1996) med 105 højrehåndede unge frivillige (42 kvinder og 63 mænd).

En mulig forklaring på den manglende konsistens mellem forsøgene kunne være, at de omhandler ret forskellige aldersgrupper og at der sker regionale 
volumenændringer gennem livet. Men dette er ikke sandsynligt, eftersom de samme studier ikke finder nogen interaktion mellem køn og alder (Chen et al. 2007, Lemaitre et al. 2005). Der er altså ikke noget i deres data, der antyder, at en sådan regional reorganisering finder sted. I hvert fald ikke i en form, der kan generaliseres på tværs af personer og køn.

En anden mulighed er, at hjernestrukturelle kønsforskelle - i det omfang de eksisterer - er subtile og at VBM som metode endnu ikke er udviklet til et stadie, hvor disse forskelle kan undersøges på en robust måde (se f.eks. Bookstein 2001). Dette efterlader selvfølgelig det åbne spørgsmål om, der findes sprogrelaterede strukturelle hjerneforskelle. Indtil videre må vi sige, at der ikke findes overbevisende data, der understøtter en sådan antagelse. 


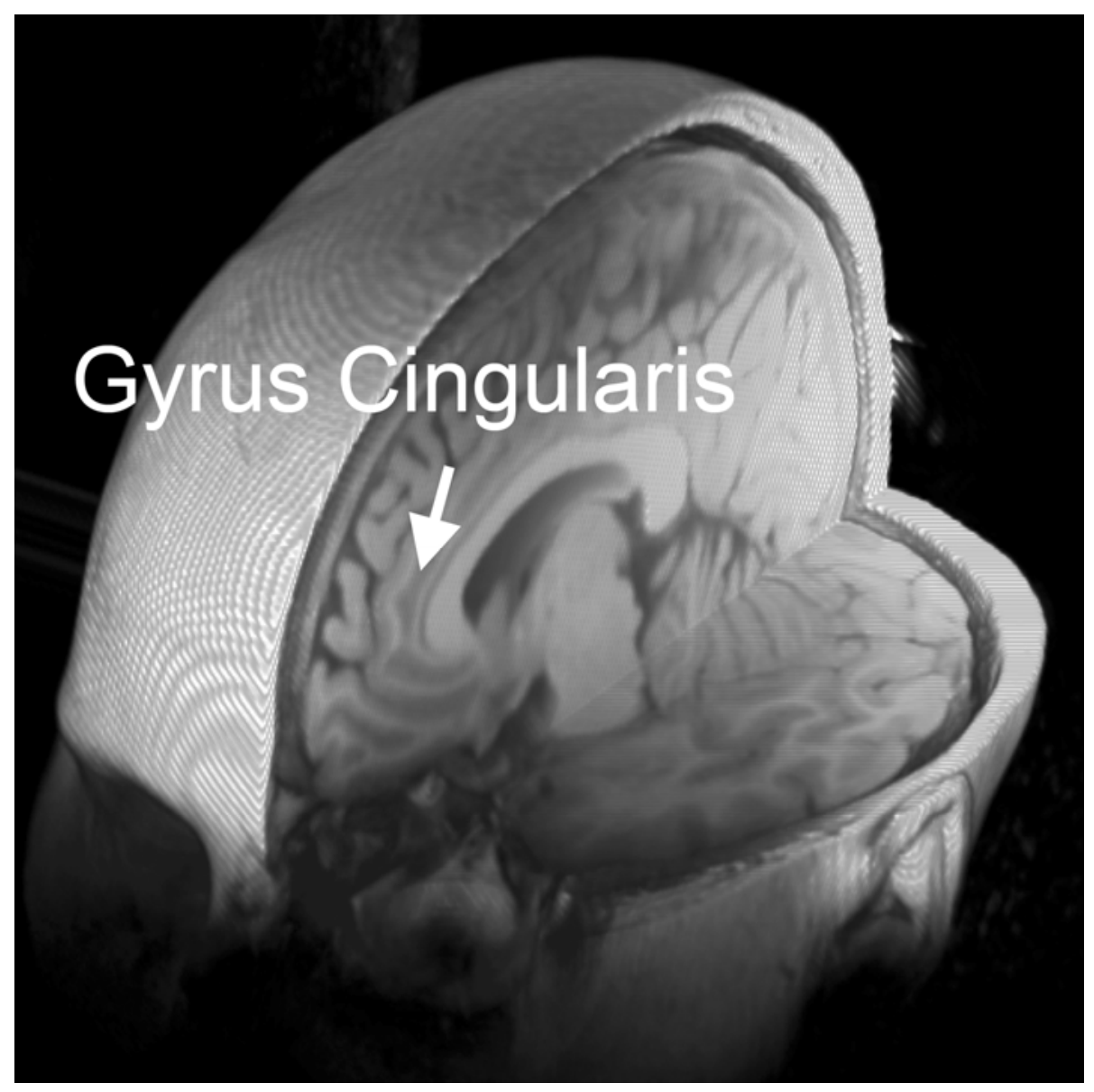

Figur 1. Gyrus Cingularis er den del af hjernen, som ligger foldet ind under det yderste cortex. I flere undersøgelser har man fundet kønsforskelle i den forreste (anteriore) del. Årsagen og effekten er ukendt.

Det skal imidlertid bemærkes, at gyrus cingularis som på tværs af flere studer giver en kønsforskel, er det område, der oftest bliver associeret med vores evner til at forstå andre menneskers handlinger og tanker. Funktionelle skanningsforsøg, der omhandler tanker om andre menneskers tanker, finder ofte aktivitet i denne region (Amodio/Frith 2006, Frith/Frith 2006). Disse evner er blandt dem som tydeligst er skadet hos patienter med autisme (Frith 2001) (se afsnit om udviklingsmæssige sprogvanskeligheder nedenfor). Hvorvidt disse observationer har relation til den større andel af autister blandt mænd vides ikke. 


\title{
3.3. Størrelsen af hjernebjælken (corpus callosum)
}

De to hjernehalvdele er forbundne via en struktur ved navn corpus callosum eller hjernebjælken. Hjernebjælken er altså et stort bundt af nervefibre, der lader information passere fra den ene hjernehalvdel til den anden. I svære tilfælde af epilepsi har man skåret denne struktur over for at forhindre spredningen af det epileptiske anfald til hele hjernen. Resultatet af denne form for indgreb er de såkaldte split brain patienter, hvor den ene hjernehalvdel i visse tilfælde ikke har adgang til de samme informationer som den anden (Gazzaniga/Sperry 1967). Med eksperimenter på denne type patienter, hvor man selektivt præsenterer stimuli til den ene del af synsfeltet (og dermed til den ene hjernehalvdel) har man kunnet iagttage, hvordan den ene side af hjernen, typisk den venstre, har meget større sproglige kompetencer end den anden. Og som nævnt ovenfor, findes der også teorier, som siger, at kvinders sprog er mindre lateraliseret end mænds (Harris 1978). Et af argumenterne bag denne antagelse er, at kvinder skulle have en større hjernebjælke end mænd og dermed bedre effektivt kunne transmittere information på tværs af hemisfærerne.

En meget benyttet dansk foredragsholder og forfatter bruger for eksempel dette argument i sin bog fra 2002 for, at der er forskel på drenge og pigers hjerner:

\begin{abstract}
For omtrent seks år siden holdt Mogens Hansen et oplæg på et tre dages seminar med psykologiforeningen [...] Han fortalte om et forskningsprojekt, som både han og hjerneforskeren Kjeld Fredens havde deltaget i [...] som gik ud på at undersøge hjernen hos piger og drenge ved skolestart. Jeg kan ikke længere huske hvor mange børn der deltog, men det var mange! [...] Forsøget viste en forskel. Hjernebjælken hos piger er næsten dobbelt så tyk som hos drenge. (Knudsen 2002: 79)
\end{abstract}

og i en nyere publikation gentages påstanden om kønsforskelle, med følgende formulering:

\footnotetext{
Allerede fra 26. fosteruge kan man måle, at pigers hjernebjælke, corpus callosum, der forbinder højre og venstre hjernehalvdel, er større end drenges. (Knudsen/Hyldig 2008: 15)
}

Og danske forfattere til populærvidenskabelige bøger er langt fra alene med påstanden om, at der er kønsforskelle i form og størrelse af hjernebjælken. 
Tværtimod bliver dette ofte fremlagt som en fasttømret sandhed, selv i højt estimerede videnskabelige tidsskrifter (f.eks. Cahill 2006).

Der er en lang historie bag opfattelsen af, at der skulle være en kønsforskel i størrelsen af hjernebjælken (se Bishop/Wahlsten 1997), men i nyere tid kan den spores tilbage til en Science-artikel af de Lacoste-Utamsing og Holloway (1982). I denne artikel rapporteres et fund af kønsforskelle $i$ arealet af tværsnit af hjernebjælken hos 9 mandlige og 5 kvindelige formalin-præparerede hjerner. Den gennemsnitlige størrelse for de to grupper var godt nok stort set identisk (mænd: $704 \mathrm{~mm}^{2}$, kvinder: $708 \mathrm{~mm}^{2}$ ), men det hævdedes, at splenium, et bestemt område i den bagerste del hjernebjælken, var mere "opsvulmet" hos kvinder end hos mænd.

Science-artiklen afstedkom en mængde andre undersøgelser. Et eksempel er Allen et al. (1991), som undersøgte MRI-billeder af 122 aldersmatchede voksne og 24 børn, halvdelen hankøn og halvdelen hunkøn. Her var fundet, at hjernebjælken overordnet var en anelse større hos mænd/drenge end hos kvinder/piger. Men igen blev det rapporteret, at den spleniale del af kvinders hjernebjælke forekom mere svulmende end mænds, der til gengæld var længere. Altså i virkeligheden ingen støtte til teorien om at kvinder har flere fibre igennem hjernebjælken, da en lang tynd struktur må formodes at kunne have lige så mange forbindelser som en kort tyk, hvis ellers volumenstørrelsen er den samme. 


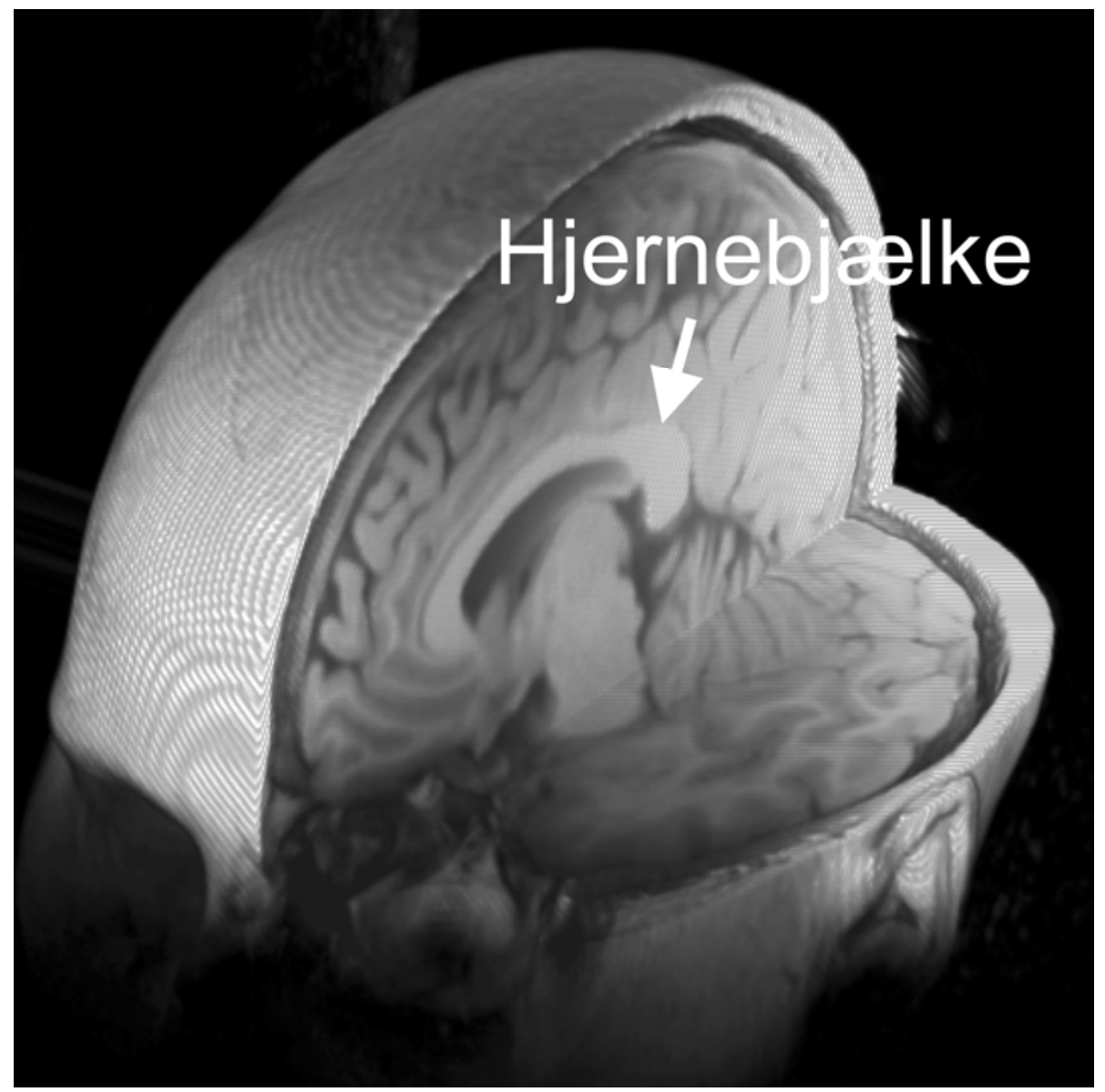

Figur 2. Hjernebjælken (corpus callosum) afbildet hos en rask forsøgsperson i et midtsagitalt snit. Pilen peger på den bagerste del af hjernebjælken (splenium), som hævdes at være større hos kvinder. Overordnet set synes der dog ingen forskel at være.

Et andet studie med strukturelle MR-billeder af 37 forsøgspersoner fandt heller ingen overordnet forskel (Byne et al. 1988). Deres konklusion var snarere, at det mest slående var den variation i størrelse og form, som kunne iagttages på tværs af individer uanset køn, hvilket peger på, hvor forsigtig man skal være med at konkludere noget på baggrund af kun 14 forsøgspersoner, som det var tilfældet $\mathrm{i}$ Science-artiklen (de Lacoste-Utamsing/Holloway 1982).

For at gøre status gennemgik Bishop/Wahlsten (1997) 49 undersøgelser af emnet. 16 af disse undersøgelser anvendte post-mortem hjerner og histologiske teknikker, mens resten byggede på strukturelle midt-sagitale MR-billeder fra 
levende individer. Konklusionen efter denne gennemgang var klar: Selv hvis der korrigeredes for forskelle i størrelse af cortex (hvor mænd som nævnt har mere grå substans), så kunne der ikke etableres nogen pålidelig forskel mellem kønnene.

Med andre ord: Den ofte omtalte kønsforskel i størrelse af hjernebjælke er en myte.

\subsubsection{Corpus callosum hos fostre og nyfødte}

Historien om at forskelle i hjernebjælkestørrelse kan måles hos fostre (se citat ovenfor) stammer fra samme de Lacoste, som igangsatte diskussionen om hjernebjælkeforskelle hos voksne. I en artikel fra 1986 (de Lacoste et al. 1986) rapporteres en observation af forskel hos fostre fra 26 ugers-alderen på en gruppe af 32 fostre mellem 26-41 uger (19 drenge, 13 piger, undersøgt post mortem). Igen er det tykkelsen af splenium, der måles til at være tykkere hos piger. Fostre og nyfødte er ikke medregnet i Bishop/Wahlstens meta-analyse (se ovenfor). Men en gennemgang af litteraturen afslører at andre med samme metode ikke har været i stand til at finde en forskel (Koshi et al. 1997). Målt med ultralydsskanning findes der dog endnu en artikel, som rapporterer større splenium hos pigefostre end hos drenge (Achiron et al. 2001). Men den nyeste undersøgelse, som jeg har kunnet finde, udført af Hwang og samarbejdspartnere (Hwang et al. 2004) fandt ingen overordnede størrelsesforskelle hos nyfødte (100 drenge, 100 piger). Formen var en anelse højere hos drenge og en anelse tykkere hos piger. Men altså overordnet set ingen forskel. Ud fra de ganske få undersøgelser, der findes, kan det altså ikke udelukkes, at en forskel hos fostre og nyfødte skulle eksistere, men videnskaben er langt fra klar på området, og det er på nuværende tidspunkt ikke muligt at sige, hvilke implikationer en større regional tykkelse, højde eller længde måtte have på hjernens funktion. Set i lyset af de negative fund hos voksne er der imidlertid ikke nogen klar begrundelse for at antage, at fostres hjernebjælker skulle være køns-differentierede.

\subsection{Strukturelle asymmetrier}

Men kønsforskelle i sprogrelateret lateralisering kunne også tænkes at stamme fra forskelle i måden mænds og kvinders hjerner er asymmetriske på.

Både kvinder og bøsser har asymmetriske hjerner, hvor hjernehalvdelene ikke er lige store. Mænd og lesbiskes 
hjernehalvdele har derimod samme størrelse. (artikel i Nyhedsavisen 18. juni 2008)

\subsubsection{Asymmetri i volumen af grå substans}

Den tidligere nævnte undersøgelse af Good og samarbejspartnere (2001) med voxel-baseret morformetri på baggrund af strukturelle MR-billeder $(n=465)$ foretog også en sammenligning af de to hjernehalvdele hos deres forsøgspersoner, for derved at sige noget om symmetriforskelle. Man fandt overordnet venstrelateralisering hos begge køn. Begge køn har altså flere hjerneceller i venstre side af hjernen, hvilket svarer til de fund, som Pakkenberg og Gundersen (1997) gjorde med celletællings-metoden (se ovenfor). Men hos Good et al. fandt man desuden, i modsætning til Pakkenberg og Gundersen, en interaktion mellem asymmetri og køn i de temporale sprogområder, sådan forstået at mænd var mere asymmetriske mod venstre i Heschls sulcus, ved overgangen til planum temporale. Dette er klassiske sprogområder (Geschwind/Levitsky 1968, Wernicke 1874), og fundet kunne altså pege på, at mænds sprog var mere venstrelateraliseret end kvinders. Gur et al. (Gur et al. 1999) fandt også, med samme metode ( $n=80)$ en ikke nærmere lokaliseret større venstrevendt asymmetri hos mænd, men dette fund skyldtes primært, at der ikke i studiet blev fundet nogen asymmetri hos kvinder overhovedet, hvilket ikke stemmer overens med Good et al.'s fund. Andre (Watkins et al. 2001) har slet ikke fundet nogen forskelle $\mathrm{i}$ asymmetri $(\mathrm{n}=124)$, og et mindre studie $(\mathrm{n}=24)$ rapporterede endda fund af højere grad af venstrevendt asymmetri hos kvinder end hos mænd i planum temporale (Knaus et al. 2004). 


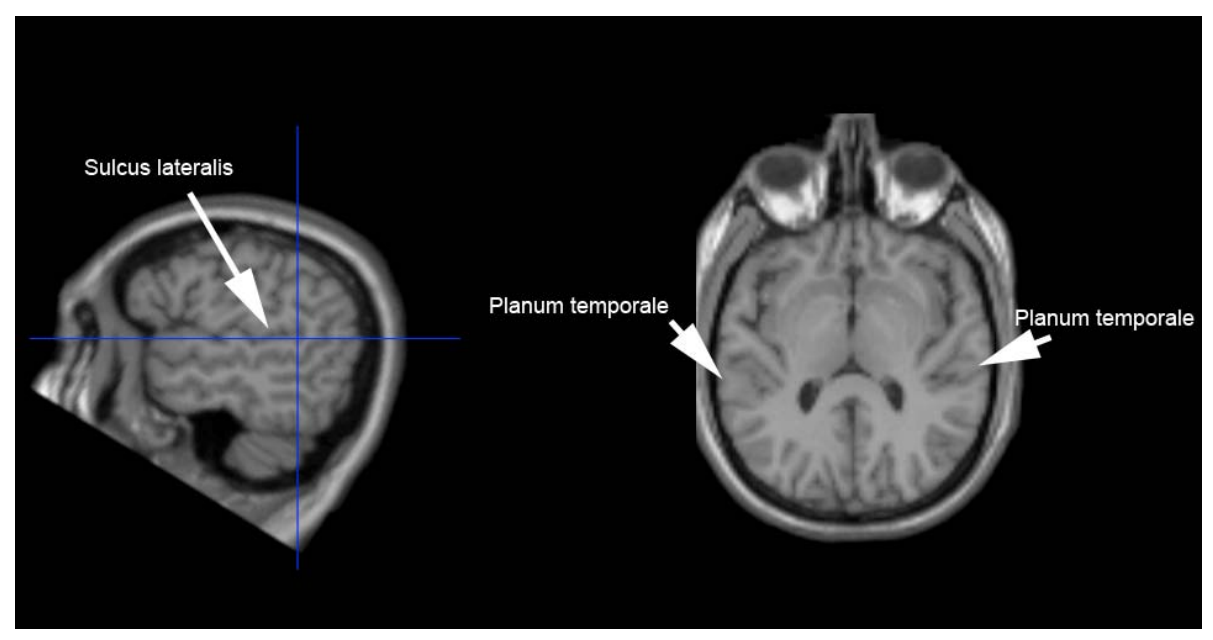

Figur 3. I et snit lagt på langs af sulcus lateralis (blå vandrette linje) ses planum temporale, hvor sprogbearbejdning bl.a. foregår. Studier har vist at planum temporale er større i venstre (sprogdominante side) end i højre. Visse studier har fundet at denne lateralisering er større hos mænd, men effekten er ikke konsistent på tværs af forsøg.

\subsubsection{Asymmetri i cortical tykkelse}

Luders et al. (2006) undersøgte forskelle i tykkelsen af grå substans på tværs af de to hjernehalvdele i 60 forsøgspersoner. Resultaterne var, at cortex globalt set er tykkere i venstre side af hjernen, og at dette er mest udtalt i motorisk cortex, i den midterste del af frontallappen, i den foreste del af temporallappen og i de superiore dele af parietallappen, mens den højre side var tykkere i den inferiore og posteriore del af temporallappen og i den inferiore del af frontallappen. Interessant nok er præcis det sidste område også et primært sprogområde, hvor man ville forvente en højere grad af venstrelateralisering. Profilen af disse asymmetrier var den samme hos begge køn, og selvom de syntes en anelse mere udtalte hos mænd, så var forskellen ikke statistisk signifikant.

Konsistente data, der peger på kønsforskelle i cortikale asymmetrier findes altså ikke på nuværende tidspunkt.

\section{KøNSFORSKELLE I SPROGFORSTYRRELSER}

\subsection{Køn og sprog i udviklingsmæssige forstyrrelser}

Udviklingsforstyrrelser, der har relevans for diskussionen om sprog og køn omfatter stammen (Halpern 2000), ordblindhed (Halpern 2000, Mildner 2008), autisme (Frith 2001) og skizofreni (Crow 2000). 


\subsubsection{Stammen}

Stammen er en letgenkendelig sprogforstyrrelse, kendetegnet ved ofte forekommende afbrydelser eller blokeringer $i$ den flydende overgang fra frembringelsen af en lyd til frembringelsen af den næste. Stammen er $\mathrm{i}$ overvejende grad en mandlig lidelse: Der er tre til fire gange flere mandlige end kvindelige stammere blandt voksne (Halpern 2000). Stammen overføres vertikalt fra generation til generation på en måde, der tyder på, at stammen har en genetisk komponent (Dworzynski et al. 2007, Kidd et al. 1981), f.eks. er der fundet større grad af sammenfald i stammen mellem brødre, der er enæggede tvillinger end mellem tveæggede tvillingebrødre (Dworzynski et al. 2007, Howie 1981). På nuværende tidspunkt er det neurale grundlag for stammen ukendt, men det vides, at personer der lider af stammen, også ofte udviser en større grad af ikke-sproglige abnormale ansigtsbevægelser (Conture/Kelly 1991, Mulligan et al. 2003) og de motoriske baner gennem basalganglierne (primært putamen), thalamus og motorisk cortex er blevet foreslået som hovedrolleindehaver $\mathrm{i}$ lidelsen (Alm 2004). Dette understøttes af det faktum, at når stammen opstår hos voksne, så er det oftest som konsekvens af skader på disse baner, mens primære sprogområder, såsom Brocas område, planum temporale, insula og Wernickes område normalt ikke findes ramt (Ludlow/Loucks 2003). Snarere end at opfatte stammen som en egentlig sproglidelse bør stammen måske derfor indskrives blandt en bredere kategori af bevægelsesforstyrrelser. Disse forstyrrelser omfatter f.eks. Parkinsons syge, som også i højere grad rammer mænd end kvinder (Mayeux et al. 1995, Van Den Eeden et al. 2003).

\subsubsection{Dysleksi (ordblindhed)}

Fordelingen af ordblinde viser også en forskel mellem mænd og kvinder, og alt efter hvilke kriterier, der anvendes, er forholdet mellem 1,6 til 1 og 4,5 til 1 (Miles et al. 1998). Diskussionen om hvorfor der er forskelle mellem kønnene $\mathrm{i}$ læsefærdigheder, er interessant, men i denne sammenhæng vil vi ikke behandle spørgsmålet i større detaljer, da det er uklart hvorvidt læsning kan betegnes som en naturlig sprogkompetence, idet de fleste ordblinde f.eks. har normale talesprogsfærdigheder. Forekomsten nævnes alligevel her i et forsøg på at give en så fordomsfri fremstilling af feltet som muligt. 


\subsubsection{Autisme}

Et andet syndrom med en udtalt skæv kønsfordeling er autisme. Der er omkring tre gange så mange mandlige autister som kvindelige (Frith 2001). Og også her kunne der være et muligt link til sprogfunktionen. Et af grundelementerne i en autismediagnose er nemlig en udtalt sprogforstyrrelse. Stumhed, forsinkelse i sprogtilegnelsen, gentagelse af tale og udpræget brug af særlige idiosynkratiske udtryk er typiske for autister. Der findes en teori, der kæder autisme sammen med en såkaldt "ekstrem mandlig hjerne" (Baron-Cohen et al. 2005), hvilket peger på, at de kognitive problemer, som autister har, måske findes blandt funktioner, hvor mænd i forvejen klarer sig dårligere end kvinder. Men i det omfang der findes en naturlig sprogfunktion, så synes den hos autister i højere grad ramt på baggrund af en mangel på evne og lyst til social omgang. En skade på det system, der muliggør vores evner for at forstå andre menneskers handlinger og tanker, altså en "blindhed for andres sind" (Baron-Cohen 1998), er den mest dominerende forklaringsmodel for, hvorfor autister har sprogproblemer. Uden en forståelse for, hvorfor andre mennesker udstøder mærkelige lyde, er det vanskeligt at tilegne sig sproglige færdigheder. Samtidig findes der mange eksempler på, at autister faktisk udvikler særdeles fremragende sproglige kompetencer (Frith 2001). Dette tyder på, at sprogdelen ikke er kernen i lidelsen, og at der muligvis er mere "mekaniske" strategier til sprogtilegnelse, som går i hvert fald delvist uden om det at forholde sig til andre menneskers indre liv.

\subsubsection{Skizofreni}

En evolutionær forbindelse mellem sprog og skizofreni relateret til seksuel udvælgelse (se ovenfor) er blevet foreslået (Crow 2000). Forekomsten af skizofreni skulle således være den evolutionære pris, vi har betalt for at have opnået vores sproglige kompetence. Det er i hvert fald et faktum, at der er kønsforskelle i symptomerne for skizofreni. Mænd får sygdommen tidligere end kvinder, selv om der ikke er store forskelle i antallet af ramte patienter. Mænd får flere negative symptomer, bl.a. i form af social tilbagetrukkethed, mangel på motivation og tale, mens kvinder i højere grad rammes af affektive symptomer, såsom depression og impulsivitet. (Leung/Chue 2000). Også her findes der studier, som rapporterer kønsforskelle i sprogkompetencer (DeLisi 2001, Walder et al. 2006), men hvis man går til en meta-analyse af over 200 forskellige 
undersøgelser, inkluderende mere end 20 forskellige kognitive variable (Heinrichs/Zakzanis 1998), så finder man at patienter med skizofreni har problemer på stort set alle fronter, inklusiv den sproglige. Dette svækker naturligvis hypotesen om, at der skulle være en særlig evolutionær forbindelse mellem sprog og skizofreni. Køn sammenlignes ikke direkte i den omtalte metaanalyse, men i alle analyser anvendes en variabel for kønsdistributionen på tværs af de 200 undersøgelser, og denne variabel giver ingen signifikant effekt. Et fald i sproglateraliseringen er også blevet foreslået som en del af symptomatologien bag skizofreni (se Sommer et al. 2001 for en meta-analyse), men i det ene lille studie (24 forsøgspersoner), som har kigget på kønsforskelle i lateraliseringen hos skizofrene blev resultatet en nul-effekt (Sommer et al. 2003).

Opsummering: Kønsforskelle findes altså i visse sprogrelaterede forstyrrelser og sygdomme, for eksempel stammen, ordblindhed, autisme og skizofreni. Ophavet til disse lidelser er stort set ukendt, men fælles for dem er, at sprogproblemer synes at være en afledt effekt, snarere end årsagen.

\subsection{Erhvervede sprogforstyrrelser}

\subsubsection{Epilepsi og tumorer: Resultater fra Wada-testen}

Wada-testen (Wada/Rasmussen 1960/2007) bruges til at undersøge lateralisering af kognitive funktioner hos primært epilepsipatienter, før de evt. skal opereres i hjernen. Et bedøvelsesmiddel indsprøjtes i en af de to halspulsårer (arteria carotis interna), som hver for sig forsyner en hjernehalvdel med blod. Derved bedøves kun den ene hjernehalvdel, og funktionen af den anden halvdel kan undergå kognitive tests. Når bedøvelsen påvirker venstre hjernehalvdel vil patienten typisk få sprogproblemer, men i et mindre antal patienter findes det primære sprogcenter enten i højre hjernehalvdel eller bilateralt fordelt, sådan at patienten opretholder talens brug både når den ene halvdel er bedøvet og når den anden er det.

To undersøgelser har ledt efter kønsforskelle i hvordan sproget rammes hos patienter under Wada-testen. Straus et al. (1992) rapporterede fund fra undersøgelser af epilepsipatienter og fandt ingen forskel mellem mænd og kvinder i antallet af patienter med atypisk (enten højrelateraliseret eller bilateral) sprogfunktion. $15 \mathrm{ud}$ af 39 mandlige patienter og $16 \mathrm{ud}$ af 55 kvindelige patienter var ikke strengt venstrelateraliserede. Helmstaedter og kolleger (1997) 
rapporterede også et nulresultat af sammenligningen mellem kønnene. I deres undersøgelse havde 22 ud af 85 mænd og 24 ud af 82 kvinder atypisk sproglateralisering.

Heller ikke data fra Wada-testen kan altså bruges til støtte for en antagelse om, at der findes funktionelle sprogrelaterede lateraliseringsforskelle mellem mænd og kvinder.

\subsubsection{Afasi efter unilateral stroke}

Blodpropper og hjerneblødninger (under ét kaldet stroke) rammer som regel i højere grad den ene hjernehalvdel end den anden. Manglen på blodtilførsel som funktion af stroke giver derfor ofte kun hjerneskader i den ene hjernehalvdel. Hvis en forskel mellem mænd og kvinders sproglateraliseringsfunktion eksisterer, så burde den blive afspejlet i en forskel i måden hvorpå mænd og kvinder rammes af afasi efter enten hjerneblødning eller blodprop. Og netop sådan en forskel er da også blevet rapporteret i litteraturen (Halpern 2000, Kimura 1983, McGlone 1980). I disse studier hævdes det, at kvinder både rammes mindre af afasi i forbindelse med stroke og hurtigere bedres efter hændelsen. Kimura (Kimura 1983) undersøgte afasi hos 143 mænd og 73 kvinder, alle højrehåndede med unilaterale læsioner i venstre halvdel af cortex. Her blev afasi rapporteret som oftere forekommende hos mænd.

Men andre stroke-undersøgelser har ikke kunnet reproducere disse fund (Basso 1992, Pedersen et al. 1995, Pedersen et al. 2004). I et stort københavnsk afasistudie deltog mere end 1.000 patienter (Pedersen et al. 1995, Pedersen et al. 2004), og her viste den indledende grad af afasi sig som den eneste klinisk relevante prædikterende faktor for, hvordan patientens sygdom udvikler sig. Køn, håndethed og side af hjerneskade var ikke i sig selv relevante prædiktorer, og alder havde kun en minimal indflydelse.

\subsubsection{Sprogforfald under normal aldring}

Hvis sprogevner er forskellige for de to køn, så burde denne forskel også kunne iagttages som forskelle i det normale forfald i sprogevnen under normal aldring. Meinz/Salthouse (1998) lavede en meta-analyse af aldringsbestemte effekter på kognitive egenskaber med data fra 25 studier (af i alt 5.201 forsøgspersoner). De 
fandt ingen kønseffekt på tværs af sprogtests, og der var ingen interaktion mellem alder og køn.

\title{
3.3. Sprog ved hormonale forstyrrelser
}

Påstanden om, at der skulle være en målbar effekt af påvirkninger fra kønshormoner på kognitionen har i dansk sammenhæng primært været fremført af tidligere professor ved psykologi på Århus Universitetet, Helmuth Nyborg (f.eks. Nyborg 1997), men kan i forskellige aftapninger også findes andre steder:

\begin{abstract}
Det er helt faktuelt: Piger og kvinder bruger hele hjernen, som den er designet til. Vi kalder det "et bredt neuralt netværk", der arbejder og lærer effektivt og uforstyrret. Drenge og mænd bliver derimod allerede fra fosterstadiet forsinkede og nødt til at udvikle alternative strategier, fordi kønshormonet testosteron forstyrrer de input, der skal bearbejdes via venstre hjernehalvdel. (Knudsen/Hyldig 2008: 15)
\end{abstract}

\subsubsection{Organisatoriske effekter: testosteron}

Kønshormonerne spiller en afgørende rolle for udviklingen af kønsspecifikke træk. En af de primære årsager til anatomiske kønsforskelle er således den hormonelle organisatoriske påvirkning fra kønskirtlerne, såsom testosteron og østrogen (Hines 2002).

Organisatoriske påvirkninger sker typisk tidligt i udviklingen, som regel i kritiske perioder, og resultaterne er permanente. Fund fra genetiske syndromer og fra tilfælde, hvor kvinder er blevet ordineret hormoner under graviditeten, peger på, at udviklingen af de ydre og indre kønsorganer hos mennesket er hormonelt styret. Høje niveauer af testikulære hormoner fremmer typisk maskulin udvikling, hvorimod fraværet af disse hormoner fremmer udviklingen af feminine strukturer.

Viden om de kognitive konsekvenser af tidlige hormonale påvirkninger stammer bl.a. fra eksempler på tvekønnethed, som i visse tilfælde vides at stamme fra abnorme hormonale påvirkninger i fosterstadiet. Et eksempel er kvinder, der har været udsat for høje niveauer af mandlige kønshormoner (androgener) i fosterstadiet på grund af kongenital adrenal hyperplasi (CAH). Mandlige kønshormoner findes i pigefostre med CAH i niveauer, der svarer til det, der findes hos drengefostre. Piger med denne lidelse fødes ofte med en vis grad af 
maskulinisering af kønsorganerne. Et antal forsøg (se Hines 2002 for en gennemgang) har undersøgt sproglige evner (bl.a. verbal fluency - se nedenfor) hos piger med $\mathrm{CAH}$ og har ikke fundet nogen forskelle $\mathrm{i}$ forhold til sammenlignelige kontrolgrupper.

Organisatorisk påvirkning fra kønshormoner kan derfor ikke på nuværende tidspunkt siges at influere udviklingen af sproglige kompetencer.

\subsubsection{Fluktuerende effekter: Progesteron og østradiol}

I forbindelse med hypoteserne om kønsforskelle i sproglateraliseringen findes også forskere, som hævder, at kvinders sproglateralisering varierer som funktion af varierende mængder af progesteron og østradiol i løbet af menstruationscyklussen (Bayer et al. 2008, Fernandez et al. 2003, Hausmann et al. 2002, Hausmann/Gunturkun 2000). Progesteron og østradiol er begge steroider, der udskilles fra kønskirtlerne, og det antages at de øgede niveauer af disse hormoner i perioden efter ægløsning:

$$
\begin{aligned}
& \text { via et fald i den transcallosale neuronale aktivering fører til } \\
& \text { en hemisfærisk dekobling og dermed til mindre funktionel } \\
& \text { asymmetri. (Hausmann/Gunturkun 2000, min oversættelse) }
\end{aligned}
$$

Kvinder tænkes altså at være mindre lateraliserede i perioden efter ægløsning og mere lateraliserede (som mænd) i menstruationsperioden. Denne kompleksitet kunne tænkes at forklare den manglende konsistens i resultaterne fra funktionelle skanningsstudier. På nuværende tidspunkt er det imidlertid ikke klart hvordan eller hvorfor sådan en variation skulle eksistere og overbevisende korrelationer mellem steroid-niveauer og lateraliserings-adfærd er ikke fundet (Bayer et al. 2008, Hausmann et al. 2002). De fund der er, er alle sammen rapporeret fra den samme forskergruppe: (Bayer et al. 2008, Hausmann et al. 2002, Hausmann/Gunturkun 2000) med brug af små grupper af forsøgsperoner $(\mathrm{n}=12-19)$. En anden gruppe $(\mathrm{n}=30)$ fandt forskelle mellem den præmenstruelle og postmenstruelle uge (Alexander et al. 2002) og kritiske forsøg på at reproducere resultaterne med større grupper $(n=55)$ har givet nul-resultat (Compton et al. 2004).

Alligevel har der været forsøg på at finde korrelationer mellem neurale sprogprocesser og hormonale fluktuationer (Fernandez et al. 2003). Sådan et 
forsøg har imidlertid et stort problem når det bliver undersøgt med funktionel magnetisk resonans-skanning (fMRI). Med fMRI måles iltindholdet i blodet, og dette bruges som indirekte mål for neural aktivitet. Problemet opstår fordi, der under menstruationscyklussen også er en variation i blodets hæmatokritværdi (Hirshoren et al. 2002), som er direkte forbundet med blodets evne til at binde ilt. Ændringer i hæmatokritværdien vides at forårsage ændringer i fMRI-signalet (Gustard et al. 2003), hvilket gør det umuligt at skelne mellem signalændringer, som skyldes hæmatokritten og signalændringer, som faktisk skyldes ændringer i hjernens aktivitet.

På nuværende tidpunkt er der derfor ikke nogen overbevisende data, der taler for at kønshormoner spiller nogen rolle for sproget.

\section{DISKUSSION}

Visse sprogrelaterede lidelser udviser klare kønsforskelle. Disse lidelser omfatter stammen, ordblindhed, skizofreni og autisme, men det er ikke åbenbart, at sprogproblemerne virkelig skyldes skader på centrale sprogprocesser. En anden forklaring kunne være, at sprogproblemet var et biprodukt af andre lidelser, f.eks. en motorisk dysfunktion for stammen og en "blindhed for andres tanker" $\mathrm{i}$ autisme.

En lille, men robust fordel i den tidlige sprogtilegnelse findes for piger. Men denne kan også ses som del af en mere generel udviklingsmæssig forsinkelse hos drenge, og tilsyneladende forsvinder forskellen omkring seks-årsalderen. Men det skal nævnes, at i visse sproglige hukommelsesopgaver synes piger at vælge en bedre strategi end drengene. Begrundelsen for dette er ukendt.

Hos voksne er kønsforskelle i sprogevner og i de underliggende hjernestrukurer og funktioner ikke robuste med nuværende målemetoder.

Denne oversigtsartikel har ikke inkluderet sociokulturelle forklaringsmodeller på de mulige kønsforskelle i sprogevner og ikke mindst sprogbrug. Havde der været klare forskelle mellem kønnene skulle sådanne forklaringsmodeller naturligvis også tages med i betragtning, før en evolutionært baseret "naturlig" forskel kunne hævdes fundet. 
Mange af de artikler, der rapporterer kønsforskelle, gør det med p-værdier, der balancerer på grænsen til det signifikante. Dette peger i retning af det såkaldte "skrivebordsproblem" eller publikations-bias (Easterbrook et al. 1991) i forskningen. Skrivebordproblematikken handler om, at et forsøgsresultat kun bliver publiceret, hvis det viser en signifikant effekt, og ingen kender derfor antallet af nul-resultater, som ligger rundt omkring i skrivebordsskufferne hos verdens forskere. Denne tendens er endnu stærkere for forskning i kønsforskelle. Kønsforskelle kan let måles og bliver nærmest rutinemæssigt analyseret i kognitive studier. Men i og med at statistiske bedømmelseskriterier resulterer i en vis procentsats falske positiver ( $5 \%$ ved alfa sat til 0.05 ), så er der en stor chance for at tilfældige målinger af kønsforskelle bliver publicerede (Hines 2002). I den sammenhæng er det interessant at notere sig, at man i metaundersøgelsen af skanningsforsøg omhandlende kønsforskelle i sproglateralisering (Sommer et al. 2004) påviste en signifikant forskel $i$ antallet af forsøgspersoner $i$ de undersøgelser der fandt og ikke fandt en kønseffekt. Forsøg der fandt en effekt havde i gennemsnit 31 forsøgspersoner, mens forsøg der ikke fandt en effekt i gennemsnit havde 76 forsøgspersoner. Fundet af kønseffekt kan altså meget vel skyldes, at visse forsøg simpelthen ikke har haft forsøgspersoner nok til sikre sig mod de typer af falske positive resultater, som man ved eksisterer $i$ skanningsforsøg. Mindst lige så interessant er det, at et stort metastudie af voksnes sprogfærdigheder fandt en signifikant effekt af førsteforfatterens køn (Hyde/Linn 1988). Dette indikerer klart, at forskere tager deres egne holdninger og kønsstereotyper med sig ind i fortolkningen af data. Det skal derfor heller ikke forsøges skjult, at forfatteren til denne artikel er en mand, og at dette kan have præget hans læsning af litteraturen.

Alligevel bliver konklusionen klar: Sprogforskelle mellem mænd og kvinder er i det store og hele ikke-eksisterende.

\section{TAKSIGELSER}

Arbejdet med denne artikel var støttet af Humanistisk fakultet på Århus Universitet, af Forskningsrådet for Kommunikation og Kultur og af Danmarks Grundforskningsfonds Center for Funktionelt Integrativ Neurovidenskab (CFIN). Forfatteren vil gerne takke Lone Frank fra Weekendavisen for at have provokeret ham til at arbejde med kønsspørgsmålet. Også tak til Torben Ellegaard Lund for input om signal-støjforhold i fMRI, til Chris Frith som ved alt om skizofreni, til 
Bente Pakkenberg for information om måling af hjernestrukturer, og til Dorthe Bleses for information om førstesprogstilegnelse. Også tak til Ethan Weed, Kristian Tylén og Andreas Roepstorff for generelle kommentarer.

\section{LITTERATUR}

Achiron, R., S. Liptz, A. Achiron (2001), "Sex-related Differences in the Development of the Human Fetal Corpus Callosum: In Utero Ultrasonographic Study", Prenatal Diagnosis 21 (2), pp. 116-120.

Alexander, G. M., M. Altemus, B. S. Peterson, B. E. Wexler (2002), "Replication of a Premenstrual Decrease in Right-Ear Advantage on Language-Related Dichotic Listening Tests of Cerebral Laterality", Neuropsychologia 40 (8), pp. 1293-1299.

Allen, L. S., M. F. Richey, Y. M. Chai, R. A. Gorski (1991), "Sex Differences in the Corpus Callosum of the Living Human Being", Journal of Neuroscience 11 (4), pp. 933-942.

Alm, P. A. (2004), "Stuttering and the Basal Ganglia Circuits: A Critical Review of Possible Relations", Journal of Communication Disorders 37 (4), pp. 325-369.

Amodio, D. M., C. D. Frith (2006), "Meeting of Minds: The Medial Frontal Cortex and Social Cognition", Nature Reviews Neuroscience 7 (4), pp. 268-277.

Ashburner, J., K. J. Friston (2000), "Voxel-Based Morphometry - The Methods", NeuroImage 11 (6), pp. 805-821.

Baron-Cohen, S. (1998), Blind for andres sind. Et essay om autisme og en teori om mentale tilstande, København: Nyt Nordisk forlag.

Baron-Cohen, S., R. C. Knickmeyer, M. K. Belmonte (2005), "Sex Differences in the Brain: Implications for Explaining Autism", Science 310 (5749), pp. 819823.

Basso, A. (1992), "Prognostic Factorsin Aphasia", Aphasiology 6 (4), pp. 337-348.

Bayer, U., N. Kessler, O. Gunturkun, M. Hausmann (2008), "Interhemispheric Interaction during the Menstrual Cycle", Neuropsychologia 46 (9), pp. 24152422 .

Berglund, E., M. Eriksson, M. Westerlund (2005), "Communicative Skills in Relation to Gender, Birth Order, Childcare and Socioeconomic Status in 18Month-Old Children", Scandinavian Journal of Psychology 46, pp. 485-491.

Bishop, K. M., D. Wahlsten (1997), "Sex Differences in the Human Corpus Callosum: Myth or Reality?", Neuroscience \& Biobehavioral Reviews 21 (5), pp. 581-601.

Bleses, D., W. Vach, M. Slott, S. Wehberg, P. Thomsen, T. O. Madsen, H. Basbøll (2008), "The Danish Communicative Developmental Inventory: Validity and Main Developmental Trends", Journal of Child Language 35, pp. 651-669.

Boles, D. B. (2005), “A Large-Sample Study of Sex Differences in Functional Cerebral Lateralization", Journal of Clinical and Experimental Neuropsychology 27 (6), pp. 759-768. 
Bookstein, F. L. (2001), “'Voxel-Based Morphometry' Should Not Be Used with Imperfectly Registered Images", NeuroImage 14, pp. 1454-1462.

Bornstein, M. H., C.-S. Hahn, O. M. Haynes (2004), "Specific and General Language Performance across Early Childhood: Stability and gender considerations", First Language 24 (3), pp. 267-305.

Broca, P. (1861), "Remarques sur le siége de la faculté du langage articulé; suives d'une observation d'aphemie", Bulletin de la Société Anatomique de Paris 6, pp. 330-357.

Byne, W., R. Bleier, L. Houston (1988), "Variations in Human Corpus Callosum Do Not Predict Gender: A Study Using Magnetic Resonance Imaging", Behavioral Neuroscience 102 (2), pp. 222-227.

Cahill, L. (2006), "Why Sex Matters for Neuroscience", Nature Reviews Neuroscience 7 (6), pp. 477-484.

Chen, X., P. S. Sachdev, W. Wen, K. J. Anstey (2007), "Sex Differences in Regional Gray Matter in Healthy Individuals Aged 44-48 Years: A Voxel-Based Morphometric Study", NeuroImage 36 (3), pp. 691-699.

Compton, R. J., C. Costello, J. Diepold (2004), “Interhemispheric Integration during the Menstrual Cycle: Failure to Confirm Progesterone-Mediated Interhemispheric Decoupling", Neuropsychologia 42 (11), pp. 1496-1503.

Conture, E. G., E. M. Kelly (1991), "Young Stutterers' Nonspeech Behaviors during Stuttering", Journal of Speech and Hearing Research 34 (5), pp. 10411056.

Crow, T. J. (2000), "Schizophrenia as the Price That Homo Sapiens Pays for Language: A Resolution of the Central Paradox in the Origin of the Species", Brain Research Reviews 31 (2-3), pp. 118-129.

de Lacoste, M. C., R. L. Holloway, D. J.Woodward (1986), "Sex Differences in the Fetal Human Corpus Callosum", Human Neurobiolgy 5 (2), pp. 93-96.

de Lacoste-Utamsing, M. C., R. L. Holloway (1982), "Sexual Dimorhism in the Human Corpus Callosum", Science 216, pp. 1431-1432.

DeLisi, L. E. (2001), "Speech Disorder in Schizophrenia: Review of the Literature and Exploration of Its Relation to the Uniquely Human Capacity for Language", Schizophrenia Bulletin 27 (3), pp. 481-496.

Dworzynski, K., A. Remington, F. Rijsdijk, P. Howell, R. Plomin (2007), "Genetic Etiology in Cases of Recovered and Persistent Stuttering in an Unselected, Longitudinal Sample of Young Twins", American Journal of Speech-Language Pathology 16 (2), pp. 169-178.

Easterbrook, P., J. Berlin, R. Gopalan, D. Matthews (1991), "Publication Bias in Clinical Research", Lancet 337 (8746), pp. 867-872.

Feldman, H. M., C. A. Dollaghan, T. F. Campbell, M. Kurs-Lasky, J. E. Janosky, J. L. Paradise (2000), "Measurement Properties of the MacArthur Communicative Development Inventories at Ages One and Two Years", Child Development 71 (2), pp. 310-322. 
Fenson, L., P. S. Dale, J. S. Reznick, E. Bates, D. J. Thal, S. J. Pethick (1994), "Variability in Early Communicative Development", Monographs of the Society for Research in Child Development 59, pp. 1-185.

Fernandez, G., S. Weis, B. Stoffel-Wagner, I. Tendolkar, M. Reuber, S. Beyenburg, P. Klaver, J. Fell, A. de Greiff, J. Ruhlmann et al. (2003), "Menstrual CycleDependent Neural Plasticity in the Adult Human Brain Is Hormone, Task, and Region Specific", Journal of Neuroscience 23 (9), pp. 3790-3795.

Frank, L. (2007), "Den store forskel”, Weekendavisen, 20. juli 2007.

Frith, C. D., U. Frith (2006), "The Neural Basis of Mentalizing", Neuron 50 (4), pp. 531-534.

Frith, U. (2001), "Mind Blindness and the Brain in Autism", Neuron 32 (6), pp. 969-979.

Galsworthy, M. J., G. Dionne, P. S. Dale, R. Plomin (2000), "Sex Differences in Early Verbal and Non-Verbal Cognitive Development", Developmental Science 3 (2), pp. 206-215.

Gannon, L. (2002), "A Critique of Evolutionary Psychology", Psychology, Evolution \& Gender 4 (2), pp. 173-218.

Gazzaniga, M. S., R. W. Sperry (1967), "Language After Section of the Cerebral Commissures", Brain 90 (1), pp. 131-148.

Geschwind, N., W. Levitsky (1968), "Human Brain: Left-Right Asymmetries in Temporal Speech Region", Science 161 (3837), pp. 186-187.

Good, C. D., I. Johnsrude, J. Ashburner, R. N. A. Henson, K. J. Friston, R. S. Frackowiak (2001), "Cerebral Asymmetry and the Effects of Sex and Handedness on Brain Structure: A Voxel-Based Morphometric Analysis of 465 Normal Adult Human Brains", NeuroImage 14, pp. 685-700.

Gray, J. (1992), Men are from Mars, Women are from Venus: A Practical Guide for Improving Communication and Getting What You Want in Your Relationships, New York: Harper Collins.

Gur, R. C., B. I. Turetsky, M. Matsui, M. Yan, W. Bilker, P. Hughett, R. E. Gur (1999), "Sex Differences in Brain Gray and White Matter in Healthy Young Adults: Correlations with Cognitive Performance", Journal of Neuroscience 19 (10), pp. 4065-4072.

Gustard, S., E. J. Williams, L. D. Hall, J. D. Pickard, T. A. Carpenter (2003), "Influence of Baseline Hematocrit on Between-Subject BOLD Signal Change Using Gradient Echo and Asymmetric Spin Echo EPI", Magnetic Resonance Imaging 21 (6), pp. 599-607.

Halpern, D. F. (2000), Sex Differences in Cognitive Abilities, Mahwah: Lawrence Erlbaum Associates.

Harris, L. J. (1978) "Sex Differences in Spatial Ability: Possible Environmental, Genetic, and Neurological Factors", in: Kinsbourne, M. (ed.) (1978), Assymetrical Function of the Brain, Cambridge: Cambridge University Press, pp. 405-522. 
Hausmann, M., C. Becker, U. Gather, O. Gunturkun (2002), "Functional Cerebral Asymmetries during the Menstrual Cycle: A Cross-Sectional and Longitudinal Analysis", Neuropsychologia 40 (7), pp. 808-816.

Hausmann, M., O. Gunturkun (2000), "Steroid Fluctuations Modify Functional Cerebral Asymmetries: The Hypothesis of Progesterone-Mediated Interhemispheric Decoupling", Neuropsychologia 38 (10), pp. 1362-1374.

Heinrichs, R. W., K. K. Zakzanis (1998), "Neurocognitive Deficit in Schizophrenia: A Quantitative Review of the Evidence", Neuropsychology 12 (3), pp. 426-445.

Helmstaedter, C., M. Kurthen, D. B. Linke, C. E. Elger (1997), "Patterns of Language Dominance in Focal Left and Right Hemisphere Epilepsies: Relation to MRI Findings, EEG, Sex, and Age at Onset of Epilepsy", Brain and Cognition 33 (2), pp. 135-150.

Hines, M. (2002), "Sexual Differentiation of Human Brain and Behavior", in: Pfaff, D. W., A. P. Arnold, S. E. Fahrbach, A. M. Etgen, R. T. Rubin (eds.) (2002), Hormones, Brain and Behavior, San Diego: Academic Press, pp. 425-462.

Hirshoren, N., I. Tzoran, I. Makrienko, Y. Edoute, M. M. Plawner, J. ItskovitzEldor, G. Jacob (2002), "Menstrual Cycle Effects on the Neurohumoral and Autonomic Nervous Systems Regulating the Cardiovascular System", Journal of Clinical Endocrinology \& Metabolism 87 (4), pp. 1569-1575.

Hofman, M. A., D. F. Swaab (1989), "The Sexually Dimorphic Nucleus of the Preoptic Area in the Human Brain: A Comparative Morphometric Study", Journal of Anatomy 164, pp. 55-72.

Howie, P. M. (1981), "Concordance for Stuttering in Monozygotic and Dizygotic Twin Pairs", Journal of Speech, Language, and Hearing Research 24 (3), pp. 317321.

Hwang, S. J., E. K. Ji, E. K. Lee, Y. M. Kim, D. Y. Shin, Y. H. Cheon, I. J. Rhyu (2004), "Gender Differences in the Corpus Callosum of Neonates", NeuroReport 15 (6), pp. 1029-1032.

Hyde, J. S., M. C. Linn (1988) "Gender Differences in Vebal Ability: A MetaAnalysis", Psychological Bulletin 104 (1), pp. 53-69.

Kansaku, K., A. Yamaura, S. Kitazawa (2000), "Sex Differences in Lateralization Revealed in the Posterior Language Areas", Cerebral Cortex 10 (9), pp. 866872.

Kidd, K. K., R. C. Heimbuch, M. A. Records (1981), "Vertical Transmission of Susceptibility to Stuttering with Sex-Modified Expression", Proceedings of the National Academy of Sciences of the United States of America 78 (1), pp. 606-610.

Kimura, D. (1983), "Sex Differences in Cerebral Organization for Speech and Praxic Functions, Canadian Journal of Psychology 37 (1), pp. 19-35.

Knaus, T. A., A. M. Bollich, D. M. Corey, L. C. Lemen, A. L. Foundas (2004), "Sex-Linked Differences in the Anatomy of the Perisylvian Language Cortex: A Volumetric MRI Study of Gray Matter Volumes", Neuropsychology 18 (4), pp. 738-747.

Knudsen, A.-E. (2002), Poene piger og dumme drenge - Hvorfor er der ingen børn der opfører sig som de har hjerne til? København: Schønberg. 
Knudsen, A.-E., K. S. Hyldig (2008), Hallo - er der hul igennem - dit barns hjerne 018 år, København: Schønberg.

Kolb, B., I. Q. Whishaw (2001), An Introduction to Brain and Behavior, New York: Worth Publishers.

Koshi, R., T. Koshi, L. Jeyaseelan, S. Vettivel (1997), "Morphology of the Corpus Callosum in Human Fetuses", Clinical Anatomy 10 (1), pp. 22-26.

Kramer, J. H., D. C. Delis, M. Daniel (1988), "Sex Differences in Verbal Learning", Journal of Clinical Psychology 44 (6), pp. 907-916.

Kramer, J. H., E. Kaplan, D. C. Delis, L. O’Donnell, A. Prifitera (1997), "Developmental Sex Differences in Verbal Learning", Neuropsychology 11 (4), pp. 577-584.

Kruggel, F. (2006), "MRI-Based Volumetry of Head Compartments: Normative Values of Healthy Adults", NeuroImage 30 (1), pp. 1-11.

Lemaitre, H., F. Crivello, B. Grassiot, A. Alpêrovitch, C. Tzourio, B. Mazoyer (2005), "Age- and Sex-Related Effects on the Neuroanatomy of Healthy Elderly", NeuroImage 26 (3), pp. 900-911.

Leung, A., P. Chue (2000), "Sex Differences in Schizophrenia, a Review of the Literature", Acta Psychiatrica Scandinavica 101 (401), pp. 3-38.

Luders, E., K. L. Narr, P. M. Thompson, D. E. Rex, L. Jancke, A. W. Toga (2006), "Hemispheric Asymmetries in Cortical Thickness", Cerebral Cortex 16 (8), pp. 1232-1238.

Ludlow, C. L., T. Loucks (2003), "Stuttering: A Dynamic Motor Control Disorder", Journal of Fluency Disorders 28 (4), pp. 273-295.

Mayeux, R., K. Marder, L. J. Cote, J. Denaro, N. Hemenegildo, H. Mejia, M.-X. Tang, R. Lantigua, D. Wilder, B. Gurland et al. (1995), "The Frequency of Idiopathic Parkinson's Disease by Age, Ethnic Group, and Sex in Northern Manhattan, 1988-1993", American Journal of Epidemiology 142 (8), pp. 820827.

McGlone, J. (1980), "Sex Differences in Human Brain Asymmetry: A Critical Survey", Behavioral and Brain Sciences 3, pp. 215-227.

Meinz, E. J., T. A. Salthouse (1998), "Is Age Kinder to Females Than to Males?", Psychonomic Bulletin \& Review 5 (1), pp. 56-70.

Mildner, V. (2008), The Cognitive Neuroscience of Human Communication, New York: Lawrence Erlbaum Associates.

Miles, T. R., M. N. Haslum, T. J. Wheeler (1998), "Gender Ratio in Dyslexia", Annals of Dyslexia 48 (1), pp. 27-55.

Miller, G. F. (2000), The Mating Mind: How Sexual Choice Shaped the Evolution of Human Nature, New York: Doubleday.

Mulligan, H. F., T. J. Anderson, R. D. Jones, M. J. Williams, I. M. Donaldson (2003), "Tics and Developmental Stuttering", Parkinsonism \& Related Disorders 9 (5), pp. 281-289.

Nyborg, H. (1997), Hormoner, Køn, og Samfund: Videnskaben om Fysikologi, København: Dansk Psykologisk Forlag. 
Nyborg, H. (2005), "Sex-Related Differences in General Intelligence g, Brain Size, and Social Status", Personality and Individual Differences 39 (3), pp. 497-509.

Nørmark, D., L. Andreassen (2007), Det virkelige menneske - Sjoelens og kulturens naturhistorie, København: People's Press.

Nørretranders, T. (2003), Det generøse menneske, København: People’s Press.

Pakkenberg, B., H. J. G. Gundersen (1997), "Neocortical Neuron Number in Humans: Effect of Sex and Age", The Journal of Comparative Neurology 384 (2), pp. 312-320.

Paus, T., N. Otaky, Z. Caramanos, D. Macdonald, A. Zijdenbos, D. d'Avirro, D. Gutmans, C. Holmes, F. Tomaiuolo, A. C. Evans (1996), "In Vivo Morphometry of the Intrasulcal Gray Matter in the Human Cingulate, Paracingulate, and Superior-Rostral Sulci: Hemispheric Asymmetries, Gender Differences and Probability Maps", The Journal of Comparative Neurology 376 (4), pp. 664-673.

Pedersen, P. M., H. S. Jørgensen, H. Nakayama, H. O. Raaschou, T. S. Olsen (1995), "Aphasia in Acute Stroke: Incidence, Determinants, and Recovery", Annals of Neurology 38, pp. 659-666.

Pedersen, P. M., K. Vinter, T. S. Olsen (2004), “Aphasia after Stroke: Type, Severity and Prognosis", Cerebrovascular Diseases 17, pp. 35-43.

Phillips, M. D., M. J. Lowe, J. T. Lurito, M. Dzemidzic, V. P. Mathews (2001), "Temporal Lobe Activation Demonstrates Sex-based Differences during Passive Listening", Radiology 220 (1), pp. 202-207.

Pinker, S. (2007), The Stuff of Thought, London: Allen Lane.

Shaywitz, B. A., S. E. Shaywitz, K. R. Pugh, R. T. Constable, P. Skudlarski, R. K. Fulbright, R. A. Bronen, J. M. Fletcher, D. P. Shankweiler, L. Katz et al. (1995), "Sex Differences in the Functional Organization of the Brain for Language", Nature 373 (6515), pp. 607-609.

Sommer, I., N. Ramsey, R. Kahn, A. Aleman, A. Bouma (2001), "Handedness, Language Lateralisation and Anatomical Asymmetry in Schizophrenia: Metaanalysis", The British Journal of Psychiatry 178 (4), pp. 344-351.

Sommer, I. E., A. Aleman, M. Somers, M. P. Boks, R. S. Kahn (2008), "Sex Differences in Handedness, Asymmetry of the Planum Temporale and Functional Language Lateralization", Brain Research 1206, pp. 76-88.

Sommer, I. E. C., A. Aleman, A. Bouma, R. S. Kahn (2004), "Do Women Really Have More Bilateral Language Representation Than Men? A Meta-Analysis of Functional Imaging Studies", Brain 127 (8), pp. 1845-1852.

Sommer, I. E. C., N. F. Ramsey, R. C. W. Mandl, R. S. Kahn (2003), "Language Lateralization in Female Patients With Schizophrenia: An fMRI Study", Schizophrenia Research 60 (2-3), pp. 183-190.

Strauss, E., J. Wada, B. Goldwater (1992), "Sex Differences in Interhemispheric Reorganization of Speech", Neuropsychologia 30 (4), pp. 353-359.

Swaab, D. F., E. Fliers (1985), "A Sexually Dimorphic Nucleus in the Human Brain", Science 228 (4703), pp. 1112-1115. 
Tombaugh, T. N., J. Kozak, L. Rees (1999), "Normative Data Stratified by Age and Education for Two Measures of Verbal Fluency: FAS and Animal Naming", Archives of Clinical Neuropsychology 14 (2), pp. 167-177.

Van Den Eeden, S. K., C. M. Tanner, A. L. Bernstein, R. D. Fross, A. Leimpeter, D. A. Bloch, L. M. Nelson (2003), "Incidence of Parkinson's Disease: Variation by Age, Gender, and Race/Ethnicity" American Journal of Epidemiology 157 (11), pp. 1015-1022.

Wada, J., T. Rasmussen (1960/2007), "Intracarotid Injection of Sodium Amytal for the Lateralization of Cerebral Speech Dominance. 1960", Journal of Neurosurgery 106 (6), ppt. 1117-1133.

Walder, D., L. Seidman, N. Cullen, J. Su, M. Tsuang, J. Goldstein (2006), "Sex Differences in Language Dysfunction in Schizophrenia", American Journal of Psychiatry 163 (3), pp. 470-477.

Wallentin, M. (2007), "En sexet historie", Weekendavisen, 24. august 2007.

Wallentin, M. (2009), "Putative Sex Differences in Verbal Abilities and Language Cortex: A Critical Review", Brain and Language 108 (3), pp. 175-183.

Watkins, K. E., T. Paus, J. P. Lerch, A. Zijdenbos, D. L. Collins, P. Neelin, J. Taylor, K. J. Worsley, A. C. Evans (2001), "Structural Asymmetries in the Human Brain: A Voxel-Based Statistical Analysis of 142 MRI Scans", Cerebral Cortex 11 (9), pp. 868-877.

Weiss, E. M., G. Kemmler, E. A. Deisenhammer, W. W. Fleischhacker, M. Delazer (2003), "Sex Differences in Cognitive Functions", Personality and Individual Differences 35 (4), pp. 863-875.

Wernicke, C. (1874), Der aphasische Symptomenkomplex, Breslau, Poland: Cohen and Weigert.

Wood, A. G., A. S. Harvey, R. M. Wellard, D. F. Abbott, V. Anderson, M. Kean, M. M. Saling, G. D. Jackson (2004), "Language Cortex Activation in Normal Children", Neurology 63 (6), pp. 1035-1044.

\section{NOTER}

1 Teorien om seksuel udvælgelse som baggrund for sprog og kreativitet bærer imidlertid på en underholdende selvmodsigelse. Hvis mænd overordnet set kun taler for at udvise overskud og dermed tiltrække sig kvinder, så bør de for enhver pris undgå at tale om Millers evolutionære teori. Analogien mellem påfuglefjerene og menneskelige egenskaber falder simpelthen ikke i god jord hos kvinder. Dertil virker teoriens egen billedliggørelse af mandlig sproglig overlegenhed alt for effektivt, selvom teoriens fortalere krampagtigt fastholder, at dette ikke er budskabet (hvilket er sandt, for budskabet er jo, hvis teorien er sand, at fortalerne bare gerne vil imponere, uanset med hvad). Fortalere for teorien er altså ikke særlig sexede og vil derfor formodentlig ikke få deres gener videreført med mindre de finder noget mere inciterende at tale om. Dermed er teorien ud fra egne evolutionære præmisser dømt til at "uddø".

2 Som interessant note til den danske sammenhæng kan nævnes at Helmuth Nyborg, den meget omtalte tidligere professor i psykologi i Århus, i sine studier af kønsforskelle blandt børn ingen forskel finder med verbal fluency-opgaven: Nyborg, H. (2005), "SexRelated Differences in General Intelligence g, Brain Size, and Social Status", Personality and Individual Differences 39 (3), pp. 497-509. 


\section{ER DER KØNSFORSKELLE I HIERNENS BEARBEJDNING AF SPROG?}

3 I skrivende stund er det seks år siden, at bogen, hvor citatet forekommer i, udkom og altså omkring tolv år siden det omtalte foredrag. Hvis man søger gennem den videnskabelige litteratur, findes der ingen henvisninger til det omtalte projekt. Og for at være helt sikker, kontaktede jeg Kjeld Fredens personligt, og han kunne forsikre mig, at det omtalte projekt aldrig har eksisteret. 